large field of opportunity in the study of methods of making farm work more attractive to the worker and more profitable both to the farmer and his men. For mutual profit is what results from better management.

\title{
FARM MANAGEMENT ACTIVITIES OF COUNTY AGENTS.
}

The following questions and answers represent a summary of farm management work taken from the county agents' annual reports for 1920 in the 33 Northern and Western States. The first column of figures indicates the number of county agents reporting on each question, and the second column gives the total figure for all counties.

\begin{tabular}{|c|c|c|}
\hline $\begin{array}{l}\text { Number } \\
\text { County } \\
\text { Agents } \\
\text { Reporting. }\end{array}$ & & $\begin{array}{c}\text { Total } \\
\text { Number }\end{array}$ \\
\hline 848 & Farm account books distributed............... & 71,642 \\
\hline $4 \mathrm{II}$ & Farmers keeping such accounts through the year....... & I9,829 \\
\hline $44 \mathrm{~T}$ & $\begin{array}{l}\text { Farmers assisted in summarizing and interpreting their } \\
\text { accounts } \ldots \ldots \ldots \ldots \ldots \ldots \ldots \ldots \ldots \ldots \ldots \ldots \ldots \ldots \ldots \ldots\end{array}$ & I I, 007 \\
\hline 209 & $\begin{array}{l}\text { Farmers making changes in their lusiness as result of } \\
\text { kceping accounts } \ldots \ldots \ldots \ldots \ldots \ldots \ldots \ldots \ldots \ldots \ldots \ldots\end{array}$ & 3,213 \\
\hline $3+4$ & $\begin{array}{l}\text { Other farmers adopting ctopging. live-stock, or complete } \\
\text { farming systcms according to recommendations...... }\end{array}$ & 7,725 \\
\hline 613 & $\begin{array}{l}\text { Farms on which buildings other than homes were con- } \\
\text { structed or remodeled according to plans furnished.... }\end{array}$ & 4,119 \\
\hline 307 & 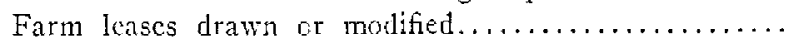 & 1,232 \\
\hline $79 \mathrm{~T}$ & Farm laborers supplicd through agent or farm bureau.. & $\mathrm{IOI}, 400$ \\
\hline 878 & $\begin{array}{l}\text { Farmers assisted in sccuring tractors, sprayers, ditching } \\
\text { machines, or other machinery to economize labor..... }\end{array}$ & $6,44 \mathrm{I}$ \\
\hline I IO & Farm Loan Associations agent assisted in organizing.... & I 44 \\
\hline 28 & Other cretit associations agent assisted in organizing.... & \\
\hline IIT & Farmers involved in the two previous questions........ & 586 \\
\hline
\end{tabular}

It should be noted that there was a total of about. I, I50 county agrents empioyed but that only a part of the agctits repotted on each question due either to having done no work along the line indicated or because data were not available with which to answer the question. In many states bankers are. now coöpcrating by distributing farm account books frce to farmers. The total number of books distributed from these two sources is far in excess of that reported by county agents. 